DOI: $10.31393 /$ reports-vnmedical-2021-25(2)-07

UDC: $572.087: 159.922$

\title{
CORRELATIONS OF ANTHROPO-SOMATOTYPOLOGICAL INDICATORS WITH INDICATORS OF PERSONALITY TRAITS OF PRACTICALLY HEALTHY WOMEN WITH ENDO-MESOMORPHIC SOMATOTYPE
}

Andriievskyi I. I.

National Pirogov Memorial Medical University, Vinnytsya, (Pyrogov street, 56, Vinnytsya, Ukraine, 21018)

Responsible for correspondence: e-mail:nolenole4@gmail.com

Received: February, 17, 2021; Accepted: March, 25, 2021

Annotation. The use of a constitutional approach makes it possible to study the individual characteristics of the organism at various levels. To harmonize various aspects of the constitution, the principle of integrity is used, which is characterized by multidimensionality, complexity and the study of the peculiarities of correlations. The purpose of the study is to establish and analyze the features of correlations between anthropo-somatotypological indicators and indicators of personality characteristics of practically healthy Ukrainian women of endomosomorphic somatotype. From the database of materials of the research center of National Pirogov Memorial Medical University, Vinnytsya selected primary indicators of personality traits and anthropo-somatotypological indicators of 22 practically healthy Ukrainian women of the first mature age of endomosomorphic somatotype. The analysis of correlations between these indicators was performed in the licensed package "Statistica 6.1" using the non-parametric Spearman's method. In women of endomosomorphic somatotype, the following multiple reliable and medium-strength unreliable connections were established: direct ( $r$ = from 0.30 to 0.59 ) index on the Eysenck insincerity scale with all indicators of the width of the distal epiphyses (WDE) of the extremities, most skin folds thicknesses (TSFF) of the upper extremity, endo- and mesomorphic components of the somatotype and fat and bone indicators of the component composition of body weight; direct ( $r=$ from 0.34 to 0.56) Eysenck extraversion-introversion index with most transverse torso dimensions; direct ( $r=$ from 0.32 to 0.53 ) Spielberger personal anxiety index with almost half of the cephalometric parameters and torso size and most pelvic size; direct ( $r=$ from 0.30 to 0.64) Shmishek stunt type accentuation index with body weight, half longitudinal, circumferential dimensions and TSFF indicators, endomorphic component of somatotype and fat and muscle indicators of body mass component composition; inverse ( $r=$ from -0.32 to -0.47 ) Shmishek emotional character accentuation index with all longitudinal dimensions, half of the indicators of WDE of the extremities, most indicators of TSFF of the upper extremity and bone index of the component composition of body weight; inverse ( $r=$ from -0.31 to -0.45) Shmishek anxiety type accentuation index with the majority of extremities and TSFF indicators, endo- and mesomorphic components of somatotype and fat and bone indicators of body weight component composition; inverse ( $r=$ from -0.46 to -0.63 ) indicator of accentuation of the character of the demonstrative type according to Shmishek with the majority of indicators of TSFF of the upper extremity; direct ( $r=$ from 0.31 to 0.61) Shmishek excitatory character accentuation index with most longitudinal dimensions, upper extremity WDE, almost half of TSFF, endomorphic somatotype component and all indicators of body weight component composition; inverse $(r=$ from -0.30 to -0.40$)$ Shmishek dysthymic character accentuation index with half of longitudinal dimensions, ectomorphic component of somatotype and bone index of body mass component composition; inverse $(r=-0.30$ to -0.75$)$, indicators of the level of subjective control in the field of achievement and family relations according to Rotter with half the girth, half the transverse dimensions of the torso and pelvis and muscle component of body weight; direct ( $r=$ from 0.34 to 0.61 ) indicators of the level of subjective control in the field of failures and educational (professional) relations according to Rotter with most longitudinal dimensions, WDE of the upper extremities (only with the level of subjective control in the field of educational (professional) relations) and bone index of the component composition of body weight. As a result of quantitative analysis of reliable and unreliable average correlations of personality indicators with anthroposomatotypological indicators of women of endomosomorphic somatotype, the highest relative percentage of relationships between: leading typological characteristics of temperament according to Eysenck and WDE extremities; psychodynamic features of personality according to Spielberger and cephalometric indicators and transverse dimensions of the body; indicators of severity and features of accentuated personality traits according to Shmishek and longitudinal body size, WDE limbs and TSFF; indicators of the level of subjective control over Rotter and the longitudinal dimensions of the body and WDE of the extremities.

Keywords: indicators of personality traits, features of body structure and size, practically healthy women of endomosomorphic somatotype, correlations.

\section{Introduction}

Typological features of the nervous system are characterized by the stability of the manifestation. The constancy of the manifestation of typological features is explained by their genetic conditionality $[16,18]$. There are a number of studies on the relationship of various mental processes with body types. It has been proved, for example, that ectomorphs are less sociable, timider, unfriendly, unhappy, but have better taste sensitivity, learn languages better, read better and have a greater vocabulary. Mesomorphs are more active, energetic, have a greater reserve of physical strength, have a good orientation in space, but learn languages worse and have less vocabulary. Endomorphs are characterized, above all, by sociability and cheerfulness, a great display of feelings, but much less enduring than the other two types [8-10]. Of course, it is possible that the greatest connection between 
body structure and mental characteristics is manifested in behavioral traits [14, 15].

Based on the concept of the organism as a whole, the hypothesis of the existence of certain constitutional types, differing in the organization and interaction of different levels of the organism, is quite adequate. In this regard, of particular interest is the relationship between body constitution, sensory systems and neurodynamics. The latter acts as a link between biological subsystems.

The purpose of the study is to establish and analyze the features of correlations between anthroposomatotypological indicators and indicators of personality characteristics of practically healthy Ukrainian women of endomosomorphic somatotype.

\section{Materials and methods}

Primary personality indicators and anthroposomatotypological indicators of practically healthy Ukrainian women of endo-mesomorphic somatotype $(n=22)$ aged 21 to 35 years were selected from the database of materials of the research center National Pirogov Memorial Medical University, Vinnytsya.

With the help of personality questionnaires [5-7, 11, 13, 17] the study of individual-personal properties of the organism was carried out.

The evaluation of the leading typological characteristics of temperament according to Eysenck G. included the definition (score): indicator on the scale of extraversionintroversion ( $A Z$ Z $E$ ), indicator on the scale of neuroticism $\left(A Z \_N\right)$ and indicator on the scale of insincerity $\left(A Z \_L\right)$.

Determination of psychodynamic personality traits by C. D. Spielberger in the modification of Y. L. Khanin included the definition (score): situational (reactive) anxiety (SP_ST) and personal anxiety (SP_LT).

Assessment of the severity and features of accentuated personality traits by $\mathrm{G}$. Shmishek included the definition (scor.): indicator of accentuation of character of hyperthymic type (SH_G), indicator of accentuation of character of stuck type ( $\mathrm{SH}_{-} \mathrm{Z}$ ), indicator of accentuation of character of emotional type (SH_EM), indicator of character accentuation (SH_P), anxiety type accentuation index $\left(\mathrm{SH}_{-} \mathrm{T}\right)$, cyclothymic type character accentuation index (SH_C), demonstrative type character accentuation index (SH_DM), excitatory type character accentuation index $(\mathrm{SH}$ _V), dysthymic type character accentuation index (SH_T) character accentuations of the exalted type (SH_EK).

Determination of the components of internality by $\mathrm{J}$. Rotter in the modification of E. F. Bazhin, S. O. Golinkina and O. M. Etkind included the definition (stan): the indicator of the scale of general internality of the level of subjective control (USK_1), the level of subjective control in the field of achievements (USK_2), the indicator of the level of subjective control in the field of failures (USK_3), the indicator of the level of subjective control in the field of family relations (USK_4), the indicator of the level of subjective control in the field of educational (professional) relations
(USK_5), the indicator of the level of subjective control in the field of interpersonal relations (USK_6) and the indicator of the level of subjective control in the field of health and disease (USK_7).

Anthropometric survey according to V. V. Bunak [3] included determination of: head size $(\mathrm{cm})$ - girth (OB_GL), maximum length (B_DL_GL), smallest width (N_SH_GL), mandibular width (SH_N_CH), sagittal arch (SAG_DUG), maximum width (B_SH_GL) and face width (SH_LICA); body weight $(\mathrm{kg})(\mathrm{W})$; longitudinal body dimensions $(\mathrm{cm})$ length $(H)$, height of the upper thoracic point (ATND), height of the pubic point (ATL), height of the acromial point (ATPL), height of the finger point (ATP) and height of the acetabulum (ATV); width of the distal epiphyses (WDE) of the long tubular bones of the limbs (cm) - shoulder (EPPL), forearm (EPPR); thighs (EPB) and shins (EPG); body circumference $(\mathrm{cm})$ - shoulder in a tense state $\left(\mathrm{OBPL}_{1}\right)$, shoulder in a relaxed state $\left(O B P L_{2}\right)$, forearm in the upper part $\left(O B P R_{1}\right)$, forearm in the lower part $\left(O B P R_{2}\right)$, thighs $(O B B)$, shins in the upper part $\left(O B G_{1}\right)$, lower legs $\left(O B G_{2}\right)$, neck $(O B S H)$, waist (OBT), thighs (OBBB), hands (OBK), feet (OBS), chest on inspiration (OBGK1), chest on exhalation $\left(\mathrm{OBGK}_{2}\right)$ and chest with calm breathing (OBGK3); transverse dimensions $(\mathrm{cm})$ - transverse mid-thoracic (PSG), transverse lowerthoracic (PNG), anterior-posterior chest size (SGK) and shoulder width (ACR), interspinous distance (SPIN), intercristal distance (CRIS), intertrochanteric distance $(\mathrm{TROCH})$ and only in women, superficial conjugates (CONJ); thickness of skin and fat folds (TSFF) (mm) - on the back surface of the shoulder (GZPL), on the front surface of the shoulder (GPPL), on the forearm (GPR), under the shoulder blade (GL), on the chest (GGR), on the abdomen (GG), on the side (GB), on the thigh (GBD) and on the shin (GGL).

Somatotype, calculated according to the scheme of $\mathrm{J}$. Carter and B. Heath [4]. It included definitions in points: endomorphic component (FX), mesomorphic component $(\mathrm{MX})$ and ectomorphic component (LX).

Fat (DM), bone (OM) and muscle (MM) components of body weight $(\mathrm{kg})$ were determined by the formulas of $\mathrm{J}$. Matiegka [12]; in addition, the muscle component of body weight (MA) - according to the method of the American Institute of Nutrition (AIN) [19].

The analysis of correlations between indicators of personality traits and indicators of body structure and size was performed in the licensed package "Statistica 6.1" using the non-parametric Spearman's method.

\section{Results. Discussion}

Table 1 presents the results of correlations between the leading typological characteristics of temperament according to Eysenck and psychodynamic features of personality according to Spielberger with indicators of body structure and size of practically healthy Ukrainian women of endomosomorphic somatotype.

Table 2 presents the results of correlations between 
Table 1. Correlations of the leading typological characteristics of temperament according to Eysenck and psychodynamic features of personality according to Spielberger with anthroposomatotypological indicators of practically healthy women of endomesomorphic somatotype $(\mathrm{n}=21-22)$.

\begin{tabular}{|c|c|c|c|c|c|}
\hline \multirow{2}{*}{ Body parameters } & \multicolumn{3}{|c|}{$\begin{array}{c}\text { Characteristics of } \\
\text { temperament }\end{array}$} & \multicolumn{2}{|c|}{$\begin{array}{c}\text { Psychodynamic } \\
\text { features of personality }\end{array}$} \\
\hline & $A Z$ E & $A Z \_N$ & $A Z \_L$ & SP_ST & SP_LT \\
\hline OB_GL & 0.00 & 0.32 & -0.29 & 0.63 & 0.40 \\
\hline B_DL_GL & -0.26 & 0.01 & -0.16 & 0.30 & 0.24 \\
\hline N_SH_GL & -0.07 & 0.15 & -0.17 & 0.00 & 0.10 \\
\hline SH_N_CH & -0.08 & 0.25 & -0.06 & -0.03 & 0.51 \\
\hline SAG_DUG & 0.12 & -0.11 & 0.16 & 0.40 & 0.07 \\
\hline B_SH_GL & -0.26 & 0.09 & -0.18 & 0.04 & 0.26 \\
\hline SH_LICA & -0.24 & 0.43 & -0.06 & 0.00 & 0.53 \\
\hline W & -0.07 & -0.06 & 0.22 & 0.11 & 0.28 \\
\hline $\mathrm{H}$ & 0.34 & -0.05 & 0.07 & 0.09 & 0.05 \\
\hline ATND & 0.35 & -0.08 & 0.25 & -0.03 & 0.10 \\
\hline ATL & 0.23 & -0.13 & 0.02 & 0.22 & 0.11 \\
\hline ATPL & 0.20 & -0.06 & 0.24 & -0.03 & 0.22 \\
\hline ATP & 0.11 & -0.14 & 0.30 & -0.13 & -0.07 \\
\hline ATV & 0.01 & -0.32 & 0.05 & 0.22 & -0.07 \\
\hline EPPL & 0.15 & -0.10 & 0.35 & -0.16 & -0.26 \\
\hline EPPR & -0.03 & 0.13 & 0.50 & 0.09 & 0.11 \\
\hline EPB & -0.07 & -0.23 & 0.32 & -0.40 & -0.22 \\
\hline EPG & 0.27 & -0.11 & 0.59 & -0.29 & -0.06 \\
\hline $\mathrm{OBPL}_{1}$ & 0.19 & 0.00 & 0.36 & -0.20 & 0.22 \\
\hline $\mathrm{OBPL}_{2}$ & 0.21 & 0.02 & 0.23 & -0.26 & 0.23 \\
\hline $\mathrm{OBPR}_{1}$ & -0.01 & 0.01 & 0.29 & -0.05 & 0.26 \\
\hline $\mathrm{OBPR}_{2}$ & -0.04 & -0.02 & 0.33 & -0.01 & 0.11 \\
\hline OBB & 0.06 & -0.06 & 0.03 & 0.08 & 0.17 \\
\hline $\mathrm{OBG}_{1}$ & 0.08 & -0.19 & 0.05 & 0.11 & -0.11 \\
\hline $\mathrm{OBG}_{2}$ & 0.07 & -0.01 & 0.14 & 0.17 & 0.00 \\
\hline $\mathrm{OBSH}$ & -0.06 & -0.03 & 0.18 & -0.08 & -0.09 \\
\hline OBT & 0.17 & -0.04 & 0.29 & -0.31 & 0.10 \\
\hline OBBB & -0.07 & -0.10 & 0.16 & -0.04 & 0.18 \\
\hline OBK & -0.03 & 0.09 & 0.29 & 0.00 & 0.13 \\
\hline OBS & -0.03 & -0.30 & 0.36 & 0.10 & -0.09 \\
\hline $\mathrm{OBGK}_{1}$ & -0.01 & -0.20 & 0.19 & -0.13 & -0.06 \\
\hline $\mathrm{OBGK}_{2}$ & 0.02 & 0.13 & 0.51 & -0.29 & 0.08 \\
\hline $\mathrm{OBGK}_{3}$ & 0.18 & -0.09 & 0.24 & -0.19 & 0.13 \\
\hline PSG & 0.34 & -0.08 & 0.07 & 0.19 & 0.32 \\
\hline PNG & 0.55 & -0.02 & 0.02 & 0.09 & 0.44 \\
\hline SGK & 0.56 & -0.33 & 0.45 & -0.33 & -0.31 \\
\hline ACR & 0.00 & -0.14 & 0.12 & 0.22 & 0.23 \\
\hline SPIN & 0.09 & 0.00 & 0.21 & 0.08 & 0.33 \\
\hline CRIS & 0.08 & -0.11 & 0.29 & -0.05 & 0.24 \\
\hline
\end{tabular}

Continuation of table 1.

\begin{tabular}{|c|c|c|c|c|c|}
\hline \multirow{2}{*}{ Body parameters } & \multicolumn{3}{|c|}{$\begin{array}{l}\text { Characteristics of } \\
\text { temperament }\end{array}$} & \multicolumn{2}{|c|}{$\begin{array}{c}\text { Psychodynamic } \\
\text { features of personality }\end{array}$} \\
\hline & AZ_E & $A Z \_N$ & $A Z \_L$ & SP_ST & SP_LT \\
\hline TROCH & 0.20 & -0.08 & 0.16 & -0.01 & 0.41 \\
\hline CONJ & -0.11 & 0.16 & 0.14 & -0.11 & 0.42 \\
\hline GZPL & -0.01 & 0.22 & 0.39 & -0.11 & -0.04 \\
\hline GPPL & 0.14 & 0.17 & 0.37 & 0.05 & 0.04 \\
\hline GPR & 0.06 & 0.06 & 0.26 & -0.13 & -0.16 \\
\hline GL & 0.03 & 0.08 & 0.37 & -0.06 & 0.20 \\
\hline GGR & -0.02 & 0.19 & 0.14 & -0.26 & -0.26 \\
\hline GG & -0.12 & -0.01 & 0.29 & -0.40 & 0.06 \\
\hline GB & -0.07 & 0.00 & 0.22 & -0.36 & -0.02 \\
\hline GBD & 0.25 & -0.24 & 0.07 & -0.06 & -0.24 \\
\hline GGL & 0.20 & -0.06 & 0.23 & -0.06 & -0.08 \\
\hline FX & -0.13 & 0.15 & 0.39 & -0.20 & 0.06 \\
\hline$M X$ & -0.07 & -0.29 & 0.40 & -0.34 & -0.23 \\
\hline$L X$ & 0.23 & 0.01 & -0.21 & -0.03 & -0.35 \\
\hline MM & 0.12 & -0.05 & 0.13 & 0.00 & 0.28 \\
\hline OM & 0.10 & -0.15 & 0.40 & -0.28 & -0.20 \\
\hline DM & 0.06 & 0.00 & 0.34 & -0.13 & -0.05 \\
\hline MA & 0.22 & -0.14 & 0.15 & -0.18 & 0.09 \\
\hline
\end{tabular}

Notes: here and in the following tables, red background - reliable strong direct correlations; magenta background - reliable mediumstrength direct correlations; yellow background - unreliable medium-strength direct correlations; green background - unreliable medium-strength feedback correlations.

the leading typological characteristics of temperament in severity and features of accentuated personality traits according to Shmishek with indicators of body structure and size of practically healthy Ukrainian women of endomosomorphic somatotype.

Table 3 presents the results of correlations between the indicators of the level of subjective control of Rotter with the indicators of body structure and size of practically healthy Ukrainian women of endomosomorphic somatotype.

In the analysis of multiple correlations between personality indicators and anthropo-somatotypological indicators of healthy women of endo-mesomorphic somatotype established: direct reliable and unreliable average strength ( $r=$ from 0.30 to 0.59 ) most indicators of TSFF of the upper extremity, endo- and mesomorphic components of the somatotype and fat and bone indicators of the component composition of body weight; mostly reliable medium-strength direct ( $r=$ from 0.34 to 0.56 ) correlations of the extraversion-introversion index according to Eysenck with most of the transverse dimensions of the torso; mostly direct reliable and unreliable average strength ( $r=$ from 0.32 to 0.53 ) correlations of Spielberger's personal anxiety index with almost half of the cephalometric indicators and torso size and most pelvic sizes; direct, mostly unreliable average strength ( $r=$ from 0.30 to 0.64 ), 
Table 2. Correlations of features of accentuated personality traits according to Shmishek with anthropo-somatotypological indicators of practically healthy women of endo-mesomorphic somatotype $(n=21-22)$.

\begin{tabular}{|c|c|c|c|c|c|c|c|c|c|c|}
\hline \multirow{2}{*}{$\begin{array}{c}\text { Body } \\
\text { parameters }\end{array}$} & \multicolumn{10}{|c|}{ Indicators of severity and features of accentuated personality traits } \\
\hline & SH_G & $\mathrm{SH} \_\mathrm{Z}$ & SH_EM & SH_P & $\mathrm{SH}_{-} \mathrm{T}$ & SH_C & SH_DM & SH_V & SH_DC & SH_EK \\
\hline OB_GL & -0.39 & -0.02 & -0.05 & 0.17 & 0.09 & 0.07 & -0.37 & 0.15 & 0.56 & -0.04 \\
\hline B_DL_GL & -0.21 & 0.19 & -0.02 & 0.12 & 0.27 & 0.00 & 0.08 & 0.12 & 0.23 & 0.06 \\
\hline N_SH_GL & -0.39 & 0.02 & 0.14 & 0.19 & 0.27 & -0.13 & 0.30 & -0.25 & 0.06 & 0.02 \\
\hline $\mathrm{SH} \_\mathrm{N} \_\mathrm{CH}$ & -0.28 & 0.05 & 0.17 & 0.27 & 0.33 & 0.02 & 0.34 & -0.03 & 0.43 & 0.19 \\
\hline SAG_DUG & 0.01 & 0.13 & -0.25 & -0.36 & 0.00 & -0.11 & -0.23 & 0.21 & 0.28 & -0.11 \\
\hline B_SH_GL & -0.24 & -0.10 & 0.23 & 0.31 & 0.39 & -0.07 & 0.08 & -0.24 & 0.12 & 0.23 \\
\hline SH_LICA & -0.22 & 0.22 & 0.00 & 0.61 & 0.31 & 0.01 & 0.08 & 0.20 & 0.31 & 0.39 \\
\hline W & -0.03 & 0.30 & -0.26 & 0.21 & 0.01 & 0.05 & 0.01 & 0.29 & 0.04 & 0.06 \\
\hline $\mathrm{H}$ & 0.18 & 0.40 & -0.43 & 0.17 & -0.07 & 0.19 & 0.03 & 0.61 & -0.32 & 0.16 \\
\hline ATND & 0.19 & 0.32 & -0.47 & 0.10 & -0.12 & 0.19 & 0.17 & 0.49 & -0.23 & 0.02 \\
\hline ATL & 0.15 & 0.13 & -0.36 & 0.02 & -0.05 & 0.23 & -0.22 & 0.50 & -0.35 & 0.09 \\
\hline ATPL & 0.17 & 0.30 & -0.35 & 0.07 & -0.03 & 0.08 & 0.16 & 0.50 & -0.17 & 0.03 \\
\hline ATP & 0.26 & -0.07 & -0.42 & -0.04 & -0.24 & 0.21 & -0.11 & 0.15 & -0.40 & -0.01 \\
\hline ATV & 0.25 & 0.26 & -0.32 & -0.10 & -0.08 & 0.03 & -0.05 & 0.36 & -0.18 & -0.12 \\
\hline EPPL & 0.34 & 0.00 & -0.41 & -0.20 & -0.37 & -0.15 & -0.12 & 0.31 & -0.26 & -0.43 \\
\hline EPPR & 0.20 & 0.08 & -0.05 & 0.05 & -0.20 & -0.25 & -0.57 & 0.39 & -0.01 & -0.11 \\
\hline EPB & 0.34 & -0.01 & -0.23 & -0.21 & -0.37 & 0.00 & 0.08 & 0.21 & -0.30 & -0.34 \\
\hline EPG & 0.39 & 0.06 & -0.46 & -0.16 & -0.36 & -0.18 & 0.03 & 0.21 & -0.26 & -0.27 \\
\hline $\mathrm{OBPL}_{1}$ & -0.04 & 0.33 & -0.02 & 0.23 & 0.09 & 0.02 & 0.20 & 0.25 & -0.15 & 0.27 \\
\hline $\mathrm{OBPL}_{2}$ & -0.07 & 0.34 & -0.02 & 0.26 & 0.10 & 0.06 & 0.33 & 0.24 & -0.13 & 0.20 \\
\hline $\mathrm{OBPR}_{1}$ & -0.09 & 0.40 & 0.00 & 0.33 & 0.20 & -0.15 & 0.06 & 0.23 & 0.04 & -0.03 \\
\hline $\mathrm{OBPR}_{2}$ & 0.22 & 0.64 & 0.10 & 0.04 & 0.02 & -0.24 & 0.13 & 0.45 & 0.13 & 0.05 \\
\hline OBB & 0.05 & 0.32 & -0.26 & 0.07 & -0.15 & 0.10 & 0.06 & 0.38 & 0.10 & -0.17 \\
\hline $\mathrm{OBG}_{1}$ & 0.01 & 0.17 & -0.34 & -0.07 & -0.31 & -0.01 & -0.15 & 0.20 & -0.06 & -0.20 \\
\hline $\mathrm{OBG}_{2}$ & 0.00 & 0.30 & -0.22 & 0.01 & -0.20 & -0.18 & -0.19 & 0.42 & 0.08 & -0.22 \\
\hline $\mathrm{OBSH}$ & 0.00 & 0.12 & -0.13 & 0.08 & 0.04 & -0.04 & 0.17 & 0.13 & -0.16 & -0.27 \\
\hline OBT & -0.12 & 0.08 & -0.09 & 0.16 & -0.05 & -0.18 & 0.18 & 0.00 & -0.17 & -0.03 \\
\hline OBBB & -0.04 & 0.14 & -0.15 & -0.01 & -0.25 & 0.02 & 0.03 & 0.27 & 0.10 & -0.01 \\
\hline OBK & 0.07 & 0.27 & 0.25 & -0.11 & 0.04 & -0.42 & 0.02 & -0.04 & 0.24 & 0.19 \\
\hline OBS & 0.22 & 0.00 & -0.10 & -0.34 & -0.11 & -0.30 & -0.22 & 0.04 & -0.11 & -0.20 \\
\hline $\mathrm{OBGK}_{1}$ & 0.21 & 0.39 & -0.10 & 0.18 & 0.12 & -0.10 & 0.40 & 0.07 & -0.24 & 0.17 \\
\hline $\mathrm{OBGK}_{2}$ & 0.03 & 0.06 & -0.03 & 0.20 & -0.15 & -0.06 & 0.06 & 0.15 & -0.13 & -0.14 \\
\hline $\mathrm{OBGK}_{3}$ & 0.10 & 0.18 & -0.05 & 0.17 & 0.04 & 0.00 & 0.31 & 0.11 & -0.21 & -0.10 \\
\hline PSG & -0.12 & -0.11 & -0.08 & 0.01 & 0.43 & -0.26 & -0.05 & -0.07 & -0.08 & -0.27 \\
\hline PNG & -0.10 & 0.11 & 0.05 & -0.05 & 0.42 & -0.23 & 0.18 & 0.16 & -0.05 & -0.21 \\
\hline SGK & 0.20 & -0.11 & -0.25 & -0.33 & -0.40 & 0.07 & 0.17 & -0.17 & -0.41 & -0.18 \\
\hline ACR & -0.15 & 0.09 & -0.21 & 0.25 & 0.24 & 0.15 & -0.04 & 0.20 & -0.08 & 0.00 \\
\hline SPIN & 0.09 & 0.35 & -0.23 & 0.15 & 0.08 & -0.25 & -0.10 & 0.39 & -0.01 & -0.07 \\
\hline CRIS & 0.20 & 0.05 & -0.15 & 0.06 & -0.06 & -0.13 & -0.09 & 0.31 & -0.16 & -0.16 \\
\hline $\mathrm{TROCH}$ & 0.11 & -0.02 & -0.28 & 0.03 & -0.12 & 0.04 & -0.10 & 0.27 & -0.08 & -0.03 \\
\hline
\end{tabular}


Continuation of table 2.

\begin{tabular}{|c|c|c|c|c|c|c|c|c|c|c|}
\hline \multirow{2}{*}{$\begin{array}{c}\text { Body } \\
\text { parameters }\end{array}$} & \multicolumn{10}{|c|}{ Indicators of severity and features of accentuated personality traits } \\
\hline & SH_G & SH_Z & SH_EM & SH_P & SH_T & SH_C & SH_DM & SH_V & SH_DC & SH_EK \\
\hline CONJ & -0.18 & 0.18 & 0.24 & 0.29 & 0.29 & -0.31 & 0.17 & -0.01 & 0.34 & 0.16 \\
\hline GZPL & 0.25 & -0.04 & -0.33 & 0.11 & -0.38 & -0.09 & -0.52 & 0.35 & -0.13 & 0.00 \\
\hline GPPL & 0.18 & -0.13 & -0.34 & 0.10 & -0.28 & 0.12 & -0.63 & 0.25 & -0.17 & -0.17 \\
\hline GPR & 0.39 & -0.26 & -0.34 & -0.02 & -0.32 & 0.09 & -0.46 & 0.18 & -0.33 & -0.31 \\
\hline $\mathrm{GL}$ & 0.16 & 0.34 & -0.17 & -0.08 & -0.33 & -0.05 & -0.09 & 0.35 & 0.09 & -0.05 \\
\hline GGR & 0.40 & -0.09 & -0.04 & -0.06 & -0.31 & -0.09 & -0.19 & 0.10 & -0.31 & -0.16 \\
\hline GG & 0.07 & 0.30 & 0.22 & 0.10 & 0.04 & -0.26 & 0.35 & 0.24 & -0.12 & -0.07 \\
\hline GB & 0.25 & 0.50 & -0.02 & 0.23 & -0.05 & -0.15 & 0.22 & 0.37 & -0.24 & -0.12 \\
\hline GBD & 0.12 & 0.34 & -0.04 & -0.17 & -0.23 & 0.02 & 0.16 & 0.23 & -0.27 & -0.12 \\
\hline GGL & 0.15 & 0.40 & -0.18 & -0.08 & -0.33 & -0.07 & 0.04 & 0.36 & -0.13 & -0.04 \\
\hline$F X$ & 0.29 & 0.47 & -0.17 & 0.19 & -0.31 & -0.14 & -0.11 & 0.51 & -0.03 & -0.07 \\
\hline $\mathrm{MX}$ & 0.17 & 0.02 & -0.12 & -0.31 & -0.32 & -0.34 & 0.08 & 0.00 & -0.11 & -0.50 \\
\hline$L X$ & 0.29 & 0.01 & -0.16 & -0.08 & -0.14 & 0.20 & 0.09 & 0.09 & -0.31 & 0.23 \\
\hline MM & -0.08 & 0.32 & -0.24 & 0.17 & 0.03 & 0.05 & 0.19 & 0.31 & 0.03 & -0.05 \\
\hline OM & 0.49 & 0.11 & -0.46 & -0.14 & -0.45 & -0.07 & -0.05 & 0.38 & -0.30 & -0.32 \\
\hline DM & 0.27 & 0.40 & -0.15 & 0.00 & -0.36 & -0.05 & -0.07 & 0.47 & -0.17 & -0.10 \\
\hline MA & -0.06 & 0.35 & 0.05 & 0.19 & 0.13 & 0.08 & 0.42 & 0.12 & -0.19 & 0.19 \\
\hline
\end{tabular}

Notes: here and in the following tables, purple background - reliable strong feedback correlations; blue background - reliable mediumstrength feedback correlations.

the correlations of the rate of accentuation of the nature of the stuck type according to Shmishek with body weight, half the longitudinal, circumferential size and TSFF, endomorphic component of somatotype and fat and muscle components body weight; inverse, mostly unreliable medium strength $(r=-0.32$ to -0.47$)$, Shmishek emotional character accentuation rate relationships with all longitudinal dimensions, half of the extremity WDE, most upper extremity TSFF and bone component of body weight composition; inverse, mostly unreliable average strength $(r=$ from -0.31 to -0.45$)$, the correlations of the rate of accentuation of the character of the anxiety type according to Shmishek with most indicators of WDE of the extremities and TSFF, endo- and mesomorphic components of somatotype and fat and bone mass of component composition body; significant inverse, mostly of medium strength ( $r=$ from -0.46 to -0.63 ), correlations of the indicator of character accentuation of the demonstrative type according to Shmishek with most indicators of TSFF of the upper extremity; direct, mostly of medium strength reliable and unreliable ( $r=$ from 0.31 to 0.61 ) correlations of Shmishek excitatory character accentuation index with most longitudinal dimensions, WDE of upper extremities, almost half of TSFF indicators, endomorphic component of somatotype and all indicators of body composition (except for muscle for AIN); medium-strength inverse unreliable ( $r$ $=-0.30$ to -0.40 ) Shmishek dysthymic character accentuation with half longitudinal dimensions, ectomorphic somatotype component, and bone mass component; inverse, mostly of medium strength, reliable and unreliable $(r=-0.30$ to -0.75$)$, the correlations of the level of subjective control in the field of achievement and family relationships according to Rotter with half the girth, half the transverse dimensions of the torso and pelvis and muscle index of the component composition of body weight; direct, mostly medium-strength, reliable and unreliable $(\mathrm{r}$ $=$ from 0.34 to 0.61 ) correlations of indicators of the level of subjective control in the field of failures and educational (professional) relations according to Rotter with most longitudinal dimensions, WDE of the upper extremities (only with the level of sub effective control in the field of educational (professional) relations) and bone index of the component composition of body weight.

Quantitative analysis of reliable and average strength of unreliable correlations between indicators of personality and body size of almost healthy women of endomesomorphic somatotype revealed the following distribution of correlations:

- with the leading typological characteristics of temperament according to Eysenck 27 correlations out of 171 possible (15.79\%), of which, $4.09 \%$ of the average strength of direct reliable and $9.95 \%$ of unreliable and $1.75 \%$ of the average strength of inverse unreliable, among which - with cephalometric indicators 2 correlations out of 21 possible (4.76\% of the average strength of direct reliable and $4.76 \%$ of unreliable); with longitudinal body size 4 
Table 3. Correlations of indicators of the level of subjective control by Rotter with anthropo-somatotypological indicators of practically healthy women of endo-mesomorphic somatotype $(n=21-22)$.

\begin{tabular}{|c|c|c|c|c|c|c|c|}
\hline \multirow{2}{*}{$\begin{array}{c}\text { Body } \\
\text { parameters }\end{array}$} & \multicolumn{7}{|c|}{$\begin{array}{c}\text { Indicators of the level of subjective control according to } \\
\text { Rotter }\end{array}$} \\
\hline & USK_1 & USK_2 & USK_3 & USK_4 4 & USK 55 & USK 6 & USK_7 \\
\hline B_GL & 0.10 & -0.06 & 0.23 & -0.25 & 0.20 & 0.39 & 0.22 \\
\hline B_DL_GL & 0.15 & 0.04 & 0.31 & -0.16 & 0.18 & 0.13 & -0.01 \\
\hline N_SH_GL & -0.24 & -0.23 & 0.10 & -0.29 & -0.12 & -0.07 & -0.08 \\
\hline SH_N_CH & -0.33 & -0.34 & -0.07 & -0.47 & -0.31 & -0.03 & -0.06 \\
\hline SAG_DUG & 0.44 & 0.26 & 0.17 & 0.09 & 0.37 & 0.39 & 0.26 \\
\hline B_SH_GL & -0.49 & -0.25 & -0.38 & -0.12 & -0.52 & -0.24 & -0.38 \\
\hline SH_LICA & -0.46 & -0.48 & -0.16 & -0.32 & -0.50 & -0.09 & -0.02 \\
\hline$w$ & 0.12 & -0.06 & 0.27 & -0.33 & 0.24 & 0.08 & 0.14 \\
\hline$\overline{\mathrm{H}}$ & 0.20 & 0.07 & $\overline{0.44}$ & -0.29 & 0.27 & 0.18 & 0.03 \\
\hline ATND & 0.25 & 0.08 & 0.49 & -0.44 & 0.32 & 0.27 & 0.04 \\
\hline ATL & 0.25 & 0.19 & 0.27 & -0.08 & 0.18 & 0.16 & -0.31 \\
\hline ATPL & 0.26 & 0.04 & 0.42 & -0.37 & 0.35 & 0.22 & 0.04 \\
\hline ATP & 0.37 & 0.33 & 0.00 & -0.09 & 0.40 & 0.08 & -0.03 \\
\hline$\overline{\text { ATV }}$ & 0.29 & 0.17 & 0.40 & -0.09 & 0.34 & 0.31 & 0.01 \\
\hline EPPL & 0.33 & 0.05 & 0.41 & -0.06 & 0.40 & 0.24 & 0.26 \\
\hline EPPR & -0.05 & -0.07 & -0.07 & -0.08 & -0.01 & -0.02 & 0.30 \\
\hline EPB & 0.43 & 0.20 & 0.17 & 0.31 & 0.58 & -0.01 & 0.01 \\
\hline EPG & 0.16 & -0.02 & 0.18 & -0.35 & 0.31 & 0.23 & 0.24 \\
\hline $\mathrm{OBPL}_{1}$ & -0.24 & -0.30 & 0.10 & -0.31 & -0.23 & -0.08 & -0.06 \\
\hline $\mathrm{OBPL}_{2}$ & -0.24 & -0.37 & 0.19 & -0.30 & -0.18 & -0.16 & -0.08 \\
\hline $\mathrm{OBPR}_{1}$ & -0.33 & -0.45 & 0.07 & -0.33 & -0.23 & -0.25 & 0.09 \\
\hline $\mathrm{OBPR}_{2}$ & 0.03 & -0.06 & 0.25 & -0.05 & -0.10 & 0.02 & 0.32 \\
\hline OBB & 0.24 & -0.05 & 0.38 & -0.18 & 0.43 & 0.04 & 0.32 \\
\hline $\mathrm{OBG}_{1}$ & 0.29 & 0.13 & 0.26 & 0.13 & 0.28 & -0.06 & 0.23 \\
\hline $\mathrm{OBG}_{2}$ & 0.04 & -0.17 & 0.32 & -0.07 & 0.07 & 0.09 & 0.35 \\
\hline $\mathrm{OBSH}$ & 0.01 & -0.09 & 0.11 & $\begin{array}{l}-0.27 \\
\end{array}$ & -0.21 & 0.15 & 0.05 \\
\hline OBT & -0.29 & -0.44 & 0.11 & -0.34 & -0.22 & -0.22 & 0.08 \\
\hline OBBB & 0.27 & 0.07 & 0.23 & 0.06 & 0.35 & -0.02 & 0.22 \\
\hline OBK & -0.05 & 0.05 & -0.04 & -0.05 & -0.13 & -0.14 & 0.34 \\
\hline OBS & 0.21 & 0.23 & 0.01 & 0.06 & 0.18 & 0.09 & 0.05 \\
\hline $\mathrm{OBGK}_{1}$ & -0.17 & -0.13 & 0.15 & -0.49 & -0.35 & 0.18 & 0.10 \\
\hline $\mathrm{OBGK}_{2}$ & -0.21 & -0.35 & 0.17 & -0.51 & -0.12 & 10 & 0.19 \\
\hline $\mathrm{OBGK}_{3}$ & -0.27 & -0.43 & 0.26 & -0.71 & -0.23 & 0.19 & 0.03 \\
\hline PSG & -0.50 & -0.65 & 0.03 & -0.75 & -0.17 & 0.07 & -0.21 \\
\hline PNG & -0.34 & -0.60 & 0.25 & -0.66 & -0.02 & -0.02 & -0.13 \\
\hline SGK & 0.04 & 0.02 & 0.26 & -0.23 & -0.05 & 0.20 & -0.10 \\
\hline ACR & -0.12 & -0.23 & 0.23 & -0.57 & 0.12 & 0.19 & -0.17 \\
\hline SPIN & -0.05 & -0.32 & 0.30 & -0.19 & -0.02 & -0.02 & 0.07 \\
\hline CRIS & -0.03 & -0.17 & 0.15 & -0.31 & 0.03 & -0.01 & -0.03 \\
\hline TROCH & 0.14 & -0.12 & 0.20 & -0.28 & 0.27 & -0.03 & -0.01 \\
\hline CONJ & -0.56 & -0.65 & -0.15 & -0.37 & -0.36 & -0.24 & 0.23 \\
\hline GZPL & 0.15 & 0.03 & -0.01 & 0.13 & 0.27 & -0.07 & 0.37 \\
\hline
\end{tabular}

Continuation of table 3.

\begin{tabular}{|l|c|c|c|c|c|c|c|}
\hline \multirow{2}{*}{$\begin{array}{c}\text { Body } \\
\text { parameters }\end{array}$} & \multicolumn{6}{|c|}{ Indicators of the level of subjective control according to } \\
\cline { 2 - 8 } & USK_1 & USK_2 & USK_3 & USK_4 & USK_5 & USK_6 & USK_7 \\
\hline GPPL & 0.05 & -0.08 & 0.13 & -0.12 & 0.28 & 0.03 & 0.01 \\
\hline GPR & 0.17 & -0.02 & 0.07 & -0.03 & $\mathbf{0 . 4 7}$ & 0.09 & 0.09 \\
\hline GL & $\mathbf{0 . 3 9}$ & 0.04 & $\mathbf{0 . 4 5}$ & 0.05 & $\mathbf{0 . 3 2}$ & 0.19 & $\mathbf{0 . 3 4}$ \\
\hline GGR & 0.17 & 0.03 & 0.14 & 0.10 & $\mathbf{0 . 3 4}$ & 0.09 & 0.29 \\
\hline GG & -0.17 & -0.30 & 0.11 & 0.05 & -0.22 & -0.24 & 0.02 \\
\hline GB & -0.10 & -0.34 & 0.23 & 0.10 & -0.14 & -0.18 & 0.11 \\
\hline GBD & 0.14 & 0.08 & $\mathbf{0 . 3 6}$ & 0.15 & -0.06 & 0.05 & -0.03 \\
\hline GGL & 0.23 & 0.10 & $\mathbf{0 . 4 2}$ & 0.09 & 0.10 & 0.03 & 0.18 \\
\hline FX & 0.15 & -0.14 & 0.29 & 0.11 & 0.07 & 0.01 & $\mathbf{0 . 4 2}$ \\
\hline MX & 0.19 & -0.07 & 0.12 & $\mathbf{0 . 3 1}$ & 0.25 & -0.10 & 0.21 \\
\hline LX & 0.18 & $\mathbf{0 . 4 1}$ & 0.07 & 0.12 & -0.09 & 0.23 & -0.15 \\
\hline MM & 0.05 & -0.19 & 0.28 & $-\mathbf{0 . 3 4}$ & 0.16 & -0.06 & 0.11 \\
\hline OM & $\mathbf{0 . 3 9}$ & 0.13 & $\mathbf{0 . 3 4}$ & 0.03 & $\mathbf{0 . 6 1}$ & 0.12 & 0.25 \\
\hline DM & 0.23 & 0.05 & $\mathbf{0 . 3 8}$ & 0.09 & 0.18 & 0.03 & 0.25 \\
\hline MA & -0.26 & -0.30 & 0.23 & $-\mathbf{0 . 4 1}$ & -0.26 & -0.02 & -0.09 \\
\hline
\end{tabular}

correlations out of 18 possible $(16.67 \%$ of the average force of direct unreliable and $5.56 \%$ of reverse unreliable); with WDE extremities 4 correlations from 12 possible (16.67 $\%$ of average force of direct reliable and $16.67 \%$ of unreliable); with a comprehensive body size 5 correlations out of 45 possible $(2.22 \%$ of the average force of direct reliable and $6.67 \%$ of unreliable, $2.22 \%$ of the average force of reverse unreliable); with transverse body size 5 correlations out of 24 possible $(12.50 \%$ of the average force of direct reliable and $4.17 \%$ of unreliable, $4.17 \%$ of the average force of the reverse unreliable); with TSFF 3 direct unreliable average force correlations from 27 possible $(11.11 \%)$; with components of somatotype 2 direct unreliable average correlations strength out of 9 possible $(22.22 \%)$; with indicators of component composition of body weight 2 direct unreliable average correlations strength out of 12 possible (16.67\%);

- with psychodynamic personality traits according to Spielberger 19 correlations out of 114 possible (16.67\%), of which, $0.88 \%$ direct strong reliable, $2.63 \%$ direct medium strong reliable and $6.14 \%$ unreliable and $7.02 \%$ reverse average strong unreliable, among which - with cephalometric indicators 6 correlations out of 14 possible $(7.14 \%$ of strong direct reliable, $14.29 \%$ of average force of direct reliable and $21.43 \%$ of unreliable); with WDE extremities 1 feedback of average force unreliable correlations from 8 possible (12.50\%); with circumferential body size 1 feedback of medium strength unreliable correlations out of 30 possible (3.33\%); with transverse body dimensions 7 correlations out of 16 possible $(6.25 \%$ of the average force of direct reliable and $25.00 \%$ of unreliable, $12.50 \%$ of the average force of inverse unreliable); with TSFF 2 average strength of unreliable feedback from 18 possible $(11.11 \%)$; with components of 
somatotype 2 of average strength of unreliable correlations from 6 possible (33.33\%);

- with indicators of severity and features of accentuated personality traits according to Shmishek 123 correlations out of 570 possible (21.58\%), of which, $0.53 \%$ strong direct reliable, $2.46 \%$ average strength direct reliable and $8.77 \%$ unreliable and $0.18 \%$ strong inverse reliable, $1.75 \%$ of the average strength of reverse reliable and $7.89 \%$ of unreliable, among which - with cephalometric indicators 15 correlations out of 70 possible (1.43\% of strong direct reliable, $2.86 \%$ of the average strength of direct reliable and $11.43 \%$ of unreliable, $5.71 \%$ of the average strength of inverse unreliable); with body weight 1 medium strength direct unreliable correlations out of 10 possible $(10.00 \%)$; with longitudinal body sizes 17 correlations out of 60 possible (1.67\% strong direct reliable, $5.00 \%$ average force direct reliable and $6.67 \%$ unreliable, $3.33 \%$ average force reverse reliable and $11.67 \%$ unreliable); with WDE extremities 14 correlations from 40 possible $(12.50 \%$ of average force of direct unreliable, $7.50 \%$ of average force of return reliable and $15.00 \%$ unreliable); with a comprehensive body size 19 correlations out of 150 possible $(0.67 \%$ strong direct reliable, $1.33 \%$ average strength direct reliable and $7.33 \%$ unreliable, $3.33 \%$ average strength reverse unreliable); with transverse body size 10 correlations out of 80 possible (1.25 $\%$ of the average force of direct reliable and $6.25 \%$ of unreliable, $5.00 \%$ of the average force of the reverse unreliable); with TSFF 26 correlations from 90 possible (1.11 $\%$ of average force of direct reliable and $12.22 \%$ of unreliable, $1.11 \%$ of strong return reliable, $2.22 \%$ of average force of return reliable and $12.22 \%$ unreliable); with components of somatotype 8 correlations from 30 possible $(6.67 \%$ of average force of direct reliable, $3.33 \%$ of average force of return reliable and $16.67 \%$ of unreliable); with indicators of component composition of body weight 13 correlations from 40 possible $(7.50 \%$ of average force of direct reliable and $12.50 \%$ of unreliable, $5.00 \%$ of average force of return reliable and $7.50 \%$ of unreliable);

- with indicators of the level of subjective control for Rotter 99 correlations out of 399 possible (24.81\%), of which, 0.25 $\%$ strong direct reliable, $1.50 \%$ average strength direct reliable and $10.53 \%$ unreliable and $1.50 \%$ strong inverse reliable, $3.51 \%$ average strength of inverse reliable and $7.52 \%$ of unreliable, among which - with cephalometric indicators 17 correlations out of 49 possible $(2.04 \%$ of average strength of direct reliable and $8.16 \%$ of unreliable, $12.24 \%$ of average strength of inverse reliable and $12.24 \%$ unreliable); with body weight 1 medium strength feedback from 7 possible (14.29\%); with longitudinal body size 14 correlations out of 42 possible $(4.76 \%$ of the average force of direct reliable and $21.43 \%$ of unreliable, $2.38 \%$ of the average force of the reverse reliable and $4.76 \%$ of unreliable); with WDE extremities 9 correlations from 28 possible (3.57 $\%$ of average force of direct reliable and $25.00 \%$ of unreliable, $3.57 \%$ of average force of return unreliable); with body circumference 23 correlations out of 105 possible $(7.61 \%$ of the average force of direct unreliable, $0.95 \%$ of strong inverse reliable, $3.81 \%$ of the average force of inverse reliable and $9.52 \%$ of unreliable); with transverse body sizes 14 correlations out of 56 possible $(1.79 \%$ of the average force of direct unreliable, $8.93 \%$ of strong inverse reliable, $5.36 \%$ of the average force of inverse reliable and $8.93 \%$ of unreliable); with TSFF 11 correlations with 63 possible $(3.17$ $\%$ of the average strength of direct reliable and $11.11 \%$ of unreliable, $3.17 \%$ of the average strength of the inverse unreliable); with components of somatotype 3 of medium strength direct unreliable correlations out of 21 possible $(14.29 \%)$; with indicators of component composition of body weight 7 correlations from 28 possible $(3.57 \%$ of strong direct reliable, $10.71 \%$ of average force of direct unreliable and $10.71 \%$ of average force of inverse unreliable).

Comparative analysis of correlations between indicators of personality traits and anthropo-somatotypological indicators in practically healthy Ukrainian women in general [1], in representatives of endomesomorphic and mesomorphic somatotype [2] revealed the presence of similar (common) patterns for all groups of comparison, and inherent in a particular type of physique quantitative and qualitative characteristics. Compared with the general group [1], one of the common characteristics of intrasystem correlations was a much larger number of connections in the groups of mesomorphs [2] and endomesomorphs, which form the size of the skull, longitudinal and transverse dimensions of the torso, TSFF and somatotype components. This indicates a significant role of the genetic component in the formation and development of personality. The difference in the percentage of such connections and their strength indirectly confirms that the personality as a whole is determined by both genetic and sociocultural influences.

Thus, the ultimate goal of constitutional anthropology is to form an idea of a single somato-mental nature of man, in particular - to determine the relationships between anthroposomatotypological indicators and other levels of human individuality: general and particular properties of the nervous system.

\section{Conclusions and prospects for further development}

1. It is established that the percentage of reliable and average strength of unreliable correlations of personality traits with anthropo-somatotypological indicators of practically healthy women of endosomorphic somatotype with leading typological characteristics of temperament according to Eysenck is $15.79 \%$ (mostly direct average strength is unreliable); with psychodynamic personality traits according to Spielberger - $16.67 \%$ (direct and inverse, mostly of medium strength are unreliable); with indicators of severity and features of accentuated personality traits according to Shmishek - $21.58 \%$ (direct and inverse, mostly of medium strength are unreliable); with indicators of the level of subjective control over Rotter - $24.81 \%$ (direct and reverse, mostly of medium strength are unreliable). 
2. The highest relative percentage of reliable and average strength of unreliable correlations between personality indicators with groups of anthropo-somatotypological indicators of women of endosomorphic somatotype was found: for the leading typological characteristics of temperament according to Eysenck - from WDE of extremities (33.34 \% of average force straight); for psychodynamic features of personality according to Spielberger - with cephalometric indicators (42.86\% of strong and average strength straight) and transverse dimensions of the body (31.25\% of average strength straight and $12.50 \%$ of inverse); for indicators of severity and features of accentuated personality traits according to Shmishek - with longitudinal body size (13.34\% strong and medium strength straight and $15.00 \%$ average strength reverse), with WDE limbs (12.50\% average strength straight and $22.50 \%$ average

\section{References}

[1] Andriievskyi, I. I., Serebrennikova, O. A., Gunas, I. V., Cherkasova, O. V., \& Kyrychenko, V. I. (2019). Correlations of anthropo-somatotypological indicators with indicators of personality traits of practically healthy Ukrainian women. Biomedical and Biosocial Anthropology, 37, 22-31. doi: 10.31393/bba37-2019-04

[2] Andriievskyi, I. I., Serebrennikova, O. A., Kyrychenko, I. M., Zhuchenko, I. I., \& Gunas, V. I. (2020). Correlations of body structure and size indicators with personality indicators of practically healthy women with mesomorphic somatotype. Biomedical and Biosocial Anthropology, 39, 35-44. doi: 10.31393/bba39-2020-06

[3] Bunak, V. V. (1941). Антропометрия: практический курс [Anthropometry: a practical course]. М.: Учпедгиз - М.: Uchpedgiz.

[4] Carter, J. L., \& Heath, B. H. (1990). Somatotyping - development and applications. Cambridge University Press.

[5] Dubrovina I. V. (1995). Руководство практического психолога: психическое здоровье детей и подростков в контексте психологической службы [Guide practical psychologist: the mental health of children and adolescents in the context of psychological services]. Москва: Академия - Moscow: Academy.

[6] Eliseev, O. P. (2010). Практикум по психологии [Workshop on psychology]. СПб: Питер. - St. Petersburg: Peter.

[7] Golovei L. A., \& Rybalko E. F. (2002). Практикум по возрастной психологии [Workshop on age psychology]. СПб.: Речь - St. Petersburg: Speech.

[8] H?bel, C., Gaspar, H. A., Coleman, J. R., Hanscombe, K. B. Purves, K., Prokopenko, I., ... \& Breen, G. (2019). Genetic correlations of psychiatric traits with body composition and glycemic traits are sex-and age-dependent. Nature communications, 10(1), 1-12. doi: 10.1038/s41467-01913544-0

[9] Ikeda, M., Tanaka, S., Saito, T., Ozaki, N., Kamatani, Y., \& Iwata, N. (2018). Re-evaluating classical body type theories: genetic correlation between psychiatric disorders and body mass index. Psychological medicine, 48(10), 1745-1748. doi: $10.1017 /$ S0033291718000685

[10] Kim, J. (2016). Personality traits and body weight: Evidence strength back) and with TSFF (13.33\% of the average force of direct and $15.55 \%$ of strong and average force of reverse); for indicators of the level of subjective control for Rotter - with longitudinal body size $(26.19 \%$ of the average force of the straight lines and $7.14 \%$ of the average force of the reverse) and with WDE of the limbs (28.57\% of the average force of the straight lines and $3.57 \%$ of the average reverse force).

Comparison and generalization of patterns of correlations between indicators of personality and anthroposomatotypological indicators in individuals with different physiques in the future research will solve one of the main tasks of health psychology - the study of different types of factors that determine motivational and situational variables. have prognostic significance in the formation of healthpreserving behavior specifically for each somatotype.

using sibling comparisons. Social Science \& Medicine, 163, 54-62. doi: 10.1016/j.socscimed.2016.06.054

[11] Krylov, А. А. (1990). Практикум по экспериментальной и прикладной психологии [Workshop on Experimental and Applied Psychology]. Л.: Изд-во Ленингр. ун-та. - L.: Publishing House of the Leningrad University.

[12] Matiegka, J. (1921). The testing of physical efficiency. Am. J. Phys. Antropol, 2(3), 25-38. doi: 10.1002/ajpa.1330040302

[13] Miroshnikov, S. A., Kravets, O. lu., Filippova, M. G., \& Chernov, R. V. (2006). Приложение к методическим материалам экспертной системы индивидуального сопровождения "Лонгитюд": описание дополнений расширенной версии "Лонгитюд+" [Appendix to the methodological materials of the expert system of individual support "Longitude": description of the additions to the extended version "Longituyd+"]. СПб. - St. Petersburg.

[14] Murphy, C. M., Stojek, M. K., \& MacKillop, J. (2014). Interrelationships among impulsive personality traits, food addiction, and body mass index. Appetite, 73, 45-50. doi: 10.1016/j.appet.2013.10.008

[15] Namatame, H., Saito, M., \& Sawamiy A. Y. (2016). Personality traits associated with body shape. International Journal of Affective Engineering, 15(2), 161-166. doi: 10.5057/ijae.IJAED-15-00021

[16] Pailhez, G., Rosado, S., Baeza-Velasco, C., \& Bulbena, A. (2014). Ectomorphic somatotype and joint hypermobility are linked in panic and agoraphobic patients: a case-control study. International journal of psychiatry in clinical practice, 18(2), 112-117. doi: 10.3109/13651501.2014.894074

[17] Raigorodskii, D. la. (2004). Практическая психодиагностика. Методики и тесты [Practical psychodiagnostics. Methods and tests]. Самара: Издательский дом "БахрахM" - Samara: Publishing House "Bahrah-M".

[18] Sutin, A. R., \& Terracciano, A. (2016). Five-factor model personality traits and the objective and subjective experience of body weight. Journal of Personality, 84(1), 102-112. doi: 10.1111/jopy. 12143

[19] Sutin, A. R., \& Terracciano, A. (2016). Personality traits and body mass index: Modifiers and mechanisms. Psychology \& health, 31(3), 259-275. doi: 10.1080/08870446.2015.1082561

\section{КОРЕЛЯЦІЇ АНТРОПО-СОМАТОТИПОЛОГІЧНИХ ПОКАЗНИКІВ ІЗ ПОКАЗНИКАМИ ОСОБЛИВОСТЕЙ ОСОБИСТОСТІ} ПРАКТИЧНО ЗДОРОВИХ ЖІНОК ЕНДО-МЕЗОМОРФНОГО СОМАТОТИПУ

\section{Андрієвський I. I.}

Анотація. Використання конституціонального підходу дає можливість досліджувати індивідуальні особливості організму на найрізноманітніших рівнях. Для узгодження різних аспектів конституції використовується принцип цілісності, який 
характеризується багатомірністю, комплексністю та вивченням особливостей кореляційних зв'язків. Мета дослідження - встановити та провести аналіз особливостей кореляцій між антропо-соматотипологічними показниками та показниками особливостей особистості практично здорових українських жінок ендо-мезоморфного соматотипу. 3 банку даних матеріалів науково-дослідного центру Вінницького національного медичного університету ім. М. І. Пирогова відібрані первинні показники особливостей особистості та антропо-соматотипологічні показники 22 практично здорових українських жінок першого зрілого віку ендо-мезоморфного соматотипу. Аналіз кореляцій між даними показниками проведено в ліцензійному пакеті "Statistica 6.1" з використанням непараметричного методу Спірмена. У жінок ендо-мезоморфного соматотипу встановлені наступні множинні достовірні та середньої сили недостовірні зв'язки: прямі (r = від 0,30 до 0,59) показника за шкалою нещирості за Eуsenck із усіма показниками ширини дистальних епіфізів (ШДЕ) кінцівок, більшістю показників товщини шкірно-жирових складок (ТШЖС) верхньої кінцівки, ендо- та мезоморфним компонентами соматотипу та жировим і кістковим показниками компонентного складу маси тіла; прямі ( $r=$ від 0,34 до 0,56) показника екстраверсії-інтроверсіі за Eysenck із більшістю поперечних розмірів тулуба; прямі ( $r=$ від 0,32 до 0,53) показника особистісної тривожності за Spielberger із майже половиною кефалометричних показників і розмірів тулуба та більшістю розмірів тазу; прямі (r = від 0,30 до 0,64) показника акцентуації характеру застрягаючого типу за Shmishek із масою тіла, половиною поздовжніх, обхватних розмірів і показників ТШЖС, ендоморфним компонентом соматотипу та жировим і м'язовим показниками компонентного складу маси тіла; зворотні ( $r$ = від -0,32 до -0,47) показника акцентуації характеру емотивного типу за Shmishek із усіма поздовжніми розмірами, половиною показників ШДЕ кінцівок, більшістю показників ТШЖС верхньої кінцівки та кістковим показником компонентного складу маси тіла; зворотні ( $r=$ від -0,31 до -0,45) показника акцентуації характеру тривожного типу за Shmishek із більшістю показників ШДЕ кінцівок і показників ТШЖС, ендо- та мезоморфним компонентами соматотипу та жировим і кістковим показниками компонентного складу маси тіла; зворотні (r = від -0,46 до -0,63) показника акцентуації характеру демонстративного типу за Shmishek із більшістю показників ТШжС верхньої кінцівки, прямі ( $r=$ від 0,31 до 0,61) показника акцентуації характеру збудливого типу за Shmishek із більшістю поздовжніх розмірів, ШДЕ верхніх кінцівок, майже половиною показників ТШЖС, ендоморфним компонентом соматотипу та усіма показниками компонентного складу маси тіла; зворотні ( $r=$ ві -0,30 до -0,40) показника акцентуації характеру дистимного типу за Shmishek із половиною поздовжніх розмірів, ектоморфним компонентом соматотипу та кістковим показником компонентного складу маси тіла; зворотні ( $r=$ від -0,30 до -0,75), показників рівня суб'єктивного контролю в галузі досягнень $і$ сімейних відносин за Rotter із половиною обхватних розмірів, половиною поперечних розмірів тулуба і розмірів тазу та м'язовим показником компонентного складу маси тіла; прямі ( $r=$ від 0,34 до 0,61) показників рівня суб'єктивного контролю в галузі невдач і навчальних (професійних) відносин за Rotter із більшістю поздовжніх розмірів, ШДЕ верхніх кінцівок (лише з рівнем суб'єктивного контролю в галузі навчальних (профресійних) відносин) та кістковим показником компонентного складу маси тіла. В результаті кількісного аналізу достовірних і недостовірних середньої сили кореляцій показників особливостей особистості з антропо-соматотипологічними показниками жінок ендо-мезоморфного соматотипу встановлено найбільший відносний відсоток зв'язків між: провідними типологічними характеристиками темпераменту за Еулепск $і$ ШДЕ кінцівок; психодинамічними особливостями особистості за Spielberger і кефалометричними показниками та поперечними розмірами тіла; показниками вираженості та особливостей акцентуйованих рис особистості за Shmishek i поздовжніми розмірами тіла, ШДЕ кінцівок і ТШЖС; показниками рівня суб'єктивного контролю за Rоtter і поздовжніми розмірами тіла та ШДЕ кінцівок.

Ключові слова: показники особливостей особистості, особливості будови та розмірів тіла, практично здорові жінки ендомезоморфного соматотипу, кореляції. 